Proceeding Paper

\title{
Assessment of Waste Heat Recovery Potential, a Case Study in a Textile Mill ${ }^{\dagger}$
}

\author{
Muhammad Nabeel ${ }^{1, *}$, Mariam Mahmood ${ }^{2}$, Naveed Ahmed ${ }^{2}$ and Azhar Iqbal ${ }^{3}$ \\ 1 Department Electrical Power Engineering, U.S.-Pakistan Center for Advanced Studies in Energy (USPCAS-E), \\ National University of Sciences and Technology, Sector H-12, Islamabad 44000, Pakistan \\ 2 Thermal Engineering Department, U.S.-Pakistan Center for Advanced Studies in Energy (USPCAS-E), \\ National University of Sciences and Technology, Sector H-12, \\ Islamabad 44000, Pakistan; mariam@uspcase.nust.edu.pk (M.M.); naveed814@yahoo.com (N.A.) \\ 3 Department of Mechanical Engineering PG Section, Cresent Textile Mills Limited Faisalabad, \\ Faisalabad 38000, Pakistan; azhariqb@ctm.com.pk \\ * Correspondence: nabeelm726@gmail.com \\ + Presented at the 1st International Conference on Energy, Power and Environment, Gujrat, Pakistan, \\ 11-12 November 2021.
}

Citation: Nabeel, M.; Mahmood, M.; Ahmed, N.; Iqbal, A. Assessment of Waste Heat Recovery Potential, a Case Study in a Textile Mill. Eng. Proc. 2021, 12, 87. https://doi.org/ 10.3390/engproc2021012087

Academic Editor: Muhammad Bilal Niazi

Published: 25 January 2022

Publisher's Note: MDPI stays neutral with regard to jurisdictional claims in published maps and institutional affiliations.

Copyright: (C) 2022 by the authors. Licensee MDPI, Basel, Switzerland. This article is an open access article distributed under the terms and conditions of the Creative Commons Attribution (CC BY) license (https:// creativecommons.org/licenses/by/ $4.0 /)$.

\begin{abstract}
The world is facing an energy crisis due to globalization and the depletion of conventional energy sources. Fossil fuels are the primary energy source used to fulfill the energy demands in industries, transportation, and residential sectors. The industrial sector consumes one third of the world's total energy, and around 50\% of the energy is eventually wasted as heat. The textile industry is one of the most energy-intensive sectors. Therefore, a lot of research has been conducted on the reduction of energy costs and associated environmental effects. The main reason for energy inefficiency is the generation of waste heat and its utilization being ignored in the developing countries. The purpose of this research is to conduct a quantitative analysis of waste heat recovery from onsite electrical power generators in a textile mill. The investigated results indicate that an annual energy saving of 90,741 MWh and 10,936 MWh can be achieved with the installation of waste heat recovery boilers and economizers at the exhaust gases ducts of internal combustion engines, respectively. Utilization of the hot water from an engine's jacket was estimated to save 30,095 MWh of energy annually. The recovered waste heat energy can be utilized in the processing unit and in the chiller section within the textile facility. The total energy saving is 131,772 MWh with a reduction of 52,708.8 tons in $\mathrm{CO}_{2}$ emissions.
\end{abstract}

Keywords: waste heat recovery; internal combustion engine; energy balance; exhaust gas recovery

\section{Introduction}

Energy is considered the backbone for a country's industrial sector's development, modernization, and economic growth, and therefore the demands are increasing worldwide. Around $32-35 \%$ of the world's total energy is used by the industrial sector and approximately half of that energy is ultimately wasted as heat [1]. Energy saving is one of the key issues, not only from the point of view of fuel consumption but also for the security of the global environment. Currently, developing countries are facing the problem of a shortage of energy, e.g., in Pakistan, the balancing of supply against demand has remained unresolved. At the present time, the country is categorized as an energy deficient state and greatly depends on imported fossil fuels, and about $88 \%$ of its energy demands are being met by non-conventional sources [2]. Textile industry is one of the most energy-intensive industries. Due to the low energy conversion efficiencies of engines, a lot of fuel energy is wasted in the form of hot exhaust gases and hot water. Various studies have been carried out for the recovery of waste heat. The exhaust from a diesel engine contains about $30 \%$ of the total input energy with an additional $16 \%$ of power improvements, and it is dependent 
on the part-load ratio. Heat exchangers have been modified which increases additional power from $16 \%$ to $23.6 \%$ [3]. Hoang, Anh Tuan et al. reviewed the latest technologies of engine waste heat recovery and concluded that conventional diesel engine efficiency is around $25 \%$ and that the engine wasted more than $60 \%$ of fuel energy, which makes it the biggest $\mathrm{CO} 2$ emission contributor [4]. Waste heat recovery from exhaust gas and jacket water simultaneously runs a $16 \mathrm{~kW}$ mixed effect absorption chiller with a cooling output of about $34.4 \mathrm{~kW}$ and a COP of 0.96 [5].

In this work, a case study was carried out in a textile mill located in Faisalabad, Pakistan. It was a vertically integrated state-of-the-art textile manufacturing mill with the production capacity of 28.8 million meters of processed dyed printed fabric per month. It is well known for the manufacturing of supreme-quality yarn, processed fabrics, home textiles, and institutional garments [6]. Energy consumption is the main concern for every industry. Here, a detailed study of power generation units was carried out for energy balance and the analysis of the recoverable potential in the whole unit. Three internal combustion engines were considered for the energy balance purpose. Each engine was analyzed for waste heat recovery potential. It was seen that about $80 \%$ of the input fuel energy could be utilized by recovering waste heat.

\section{Methodology}

The textile mill has its own in-house captive power plant. The total installed capacity is $26 \mathrm{MW}$, and about $80 \%$ of the total electricity demand is generated by their own in-house PG unit. The backup generation includes two dedicated feeders with a combined capacity of $6 \mathrm{MW}$ from FESCO, and furnace oil generators with a combined capacity of $4.8 \mathrm{MW}$.

Two natural gas-fired Wärtsilä engines, i.e., engines 1 and 2, are identical and have almost the same trends for their continuous operation. Engine 3 is a Wärtsilä dual fuel combustion engine. The details and specifications of engines are given in the Table 1.

Table 1. Engines' specifications.

\begin{tabular}{ccc}
\hline Manufacturer & Wärtsilä Gas Fired & Wärtsilä Dual Fuel \\
\hline RPM & 1800 & $720-750$ \\
\hline Fuel type & Natural Gas & Dual Fuel \\
\hline Ignition System & WECS-3000 & SVOICE \\
\hline Cooling system & Cooling tower & Cooling tower \\
\hline
\end{tabular}

The engines run for almost $24 \mathrm{~h}$ a day at constant load. The overall efficiency of engines 1, 2 and engine 3 is around 42\% and 37\%, respectively. Engines 1 and 2 consume about $455.45 \mathrm{Hm} 3$ (228.73 Hm3 each) of gas, generate $185 \mathrm{MWh}$ of electricity on average in a day, and the rest of the $264 \mathrm{MWh}$ of energy is wasted. Engine 3 consumes about 194.87 Hm3 of gas, produces 69.8 MWh of electricity on average, and 120 MWh is wasted.

\subsection{Waste Heat Recovery Boiler}

WHR boilers are installed on individual unit's exhaust duct. Engines 1 and 2 and engine 3 have a capacity of 3 ton $/ \mathrm{h}$ and $2.8 \mathrm{ton} / \mathrm{h}$, respectively. The specifications of the boilers are given in Table 2.

Table 2. Engine specifications.

\begin{tabular}{ccc}
\hline Parameters & 3 TPH WHR Boiler & 2.8 TPH WHR Boiler \\
\hline Boiler Type & Horizontal-FireTube & Horizontal-FireTube \\
\hline Efficiency & $94 \%$ & $93 \%$ \\
\hline Economizer & Installed & Installed \\
\hline Blow down & Manual & Manual \\
\hline
\end{tabular}




\subsection{Cooling System}

Two lines, i.e., LT (Low temperature) and HT (High temperature), are used for engine cooling. When fresh air passes through the turbo charger, it gets heated. The LT line is used to cool down fresh air to a specific temperature. The HT line is a closed-loop water cooling line between the engine and cooling tower.

\section{Results and Discussions}

The overall heat balance of the engines is given in the Figure $1 \mathrm{a}$. Figure $1 \mathrm{~b}$ is the energy balance of identical engines 1 and 2 , and Figure $1 b$ is the energy balance of engine 3 .

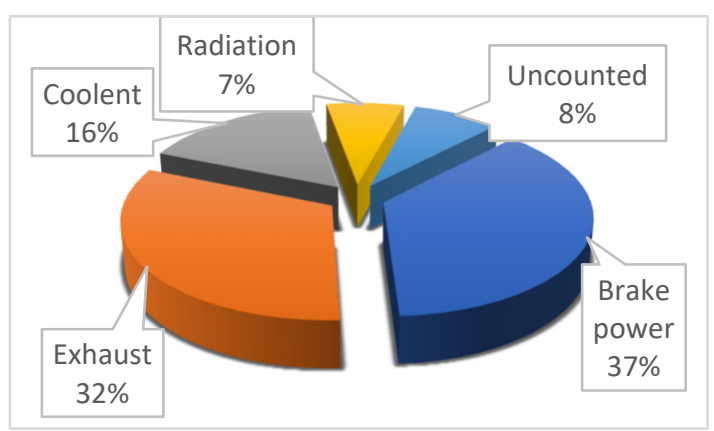

(a)

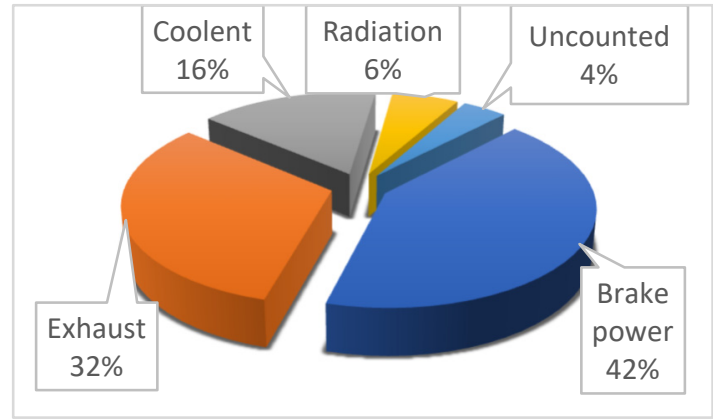

(b)

Figure 1. Heat balance of engines: (a) Wärtsilä dual fuel (b) Wärtsilä gas fired.

\subsection{WHR from Exhaust}

The quantity of waste heat is a function of both the temperature and the mass flow rate.

$$
Q=\Uparrow C_{p} \Delta T
$$

where $Q$ is the heat loss $(\mathrm{kJ} / \mathrm{min}), \mathbb{1}$ is the exhaust gas mass flow rate $(\mathrm{kg} / \mathrm{min}), C_{p}$ is the specific heat of exhaust gas $(\mathrm{kJ} / \mathrm{kg} \mathrm{K})$, and $\Delta T$ is the temperature difference in $\mathrm{K}$.

Heat content available and the recoverable heat from the exhaust gases of engines in $\mathrm{Kw}$ is given in the Table 3.

Table 3. Energy extracted from exhaust gases.

\begin{tabular}{cccc}
\hline Entry & Wärtsilä Gas Fired & Wärtsilä Dual Fuel & UOM \\
\hline Total Energy to Exhaust & 4522 & 2321 & $\mathbf{K w}$ \\
\hline Heat recovery in WHR boiler & 1888 & 781 & $\mathbf{K w}$ \\
\hline Heat recovery in Economizer & 416 & 190 & $\mathbf{K w}$ \\
\hline Heat rejection in chimney & 1085 & 481 & $\mathbf{K w}$ \\
\hline
\end{tabular}

\subsection{Energy Extracted from Jacket Water}

The details of engine jacket water parameters are described in the Table 4.

Table 4. Engines jacket water parameters.

\begin{tabular}{cccc}
\hline Parameters & Wärtsilä Gas Fired & Wärtsilä Dual Fuel & UOM \\
\hline HT temp in & 92 & 86 & ${ }^{\circ} \mathrm{C}$ \\
\hline HT temp out & 86 & 79 & ${ }^{\circ} \mathrm{C}$ \\
\hline Water flow rate & 180 & 160 & $\mathrm{~m}^{3} / \mathrm{h}$ \\
\hline
\end{tabular}


The energy wasted in the jacket water of engines 1 and 2 and engine 3 is $1221 \mathrm{KW}$ and $543 \mathrm{KW}$, respectively. This heat is rejected in the cooling towers.

\section{Conclusions}

The investigated results indicate that an annual energy saving of 90,741 MWh and 10,936 MWh can be achieved with the installation of waste heat recovery boilers and economizers at the exhaust gases ducts of internal combustion engines, respectively. Utilization of hot water from an engine's jacket was estimated to save 30,095 MWh of energy annually. The recovered waste heat energy is utilized in the processing unit and chiller section within the textile facility. The total energy saving is 131,772 MWh with a reduction of $52,708.8$ tons in $\mathrm{CO}_{2}$ emissions. Energy loss at blowdown of WHRB can also be minimized by the automation of the blowdown system, which can save energy. Proper monitoring of steam leakages at steam headers and control valves can also contribute to significant energy saving.

Author Contributions: Conceptualization, M.N. and M.M.; methodology, M.N.; validation, M.N., M.M. and N.A.; formal analysis, M.N.; investigation, M.N. and A.I.; resources, A.I. and M.M.; writing—original draft preparation, M.N.; writing—review and editing, M.M. and N.A.; supervision, M.M. All authors have read and agreed to the published version of the manuscript.

Funding: This research received no external funding.

Institutional Review Board Statement: Not applicable.

Informed Consent Statement: Not applicable.

Data Availability Statement: Not applicable.

Acknowledgments: Authors are grateful to the management and staff of Cresent Textile Mills Limited (CTM), Faisalabad, for their cooperation.

Conflicts of Interest: The authors declare no conflict of interest.

\section{References}

1. Dong, G.; Morgan, R.; Heikal, M. A novel split cycle internal combustion engine with integral waste heat recovery. Appl. Energy 2015, 157, 744-753. [CrossRef]

2. Ahmed, N.; Khan, A.N.; Ahmed, N.; Aslam, A.; Imran, K.; Sajid, M.B.; Waqas, A. Techno-economic potential assessment of mega scale grid-connected PV power plant in five climate zones of Pakistan. Energy Convers. Manag. 2021, 237, 114097. [CrossRef]

3. Hoang, A.T. Waste heat recovery from diesel engines based on Organic Rankine Cycle. Appl. Energy 2018, 231, 138-166. [CrossRef]

4. Wang, J.; Wu, J. Investigation of a mixed effect absorption chiller powered by jacket water and exhaust gas waste heat of internal combustion engine. Int. J. Refrig. 2015, 50, 193-206. [CrossRef]

5. Jadhao, J.S.; Thombare, D.G. Review on exhaust gas heat recovery for IC engine. Int. J. Eng. Innov. Technol. $2013,97$.

6. Crescenttextile.Com. Available online: https://www.crescenttextile.com/company-profile/ (accessed on 12 September 2021). 